\title{
Effect of Bank Commitment, Bank Communication and Handling Customer Complaint on Customer Loyalty through Customer Satisfaction at PT Bank Central Asia Tbk of Mojopahit Mojokerto Sub-Branch Office
}

\author{
R. Sapto Roedy Widijanto; Basuki Rachmat \\ Graduate Program in Management STIE Perbanas Surabaya, Indonesia
}

http://dx.doi.org/10.18415/ijmmu.v6i2.756

\begin{abstract}
This research aims to analyze the effect of bank commitment, bank communication, and handling customer complaint on customer loyalty through customer satisfaction. This is a correlational research that uses a quantitative approach by applying SEM (Structural Equation Model) analysis. The research sampling used a purposive sampling technique that obtained 165 samples from customers. The results of this research include: 1) CR value between Bank Commitment and Customer Satisfaction is 3.469; 2) the CR value between Bank Commitment and Customer Loyalty is 2017; 3) the CR value between Bank Communication and Customer Satisfaction is 3.318; 4) CR value between Bank Communication and Customer Loyalty is 2.494; 5) CR value between Handling Customer Complaint and Customer Satisfaction is 2.322 ; 6) CR value between Handling Customer Complaint and Customer Loyalty is 2.365 ; 7) CR value between Customer Satisfaction and Customer Loyalty is 2.414 ; 8) the estimate value of direct effect of Bank Commitment on Customer Loyalty is 0.193; 9) the estimate value of direct effect of Bank Communication on Customer Loyalty is $0.251 ; 10$ the estimate value of direct effect of Handling Customer Complaint on Customer Loyalty is 0.224 . The conclusion of this research is that all variables have significant effect.
\end{abstract}

Keywords: Commitment; Communication; Customer Complaint; Loyalty; Customer Satisfaction

\section{Introduction}

Banking is a sector that plays an important role in business development in the economic field; especially in the improvement of equitable development, economic growth of the community, as well as stability in increasing the living tariff of the community. Banking is a sector that becomes the main source of state finance because there are many economic activities, especially distribution, production, and other activities that have a relationship with the banking sector as financial institution and source of funding and functioning storage so that business activities run smoothly (Danibrata, 2011).

The broader business development related to products and services in the banking world has an impact on increasingly competitive competition between banks, especially in marketing their products. Competition can create new ideas that can create strategies to compete in marketing products. In an effort to survive in the midst of intense competition, banks must have very high-quality step called the competitive strategy. 
According to Robinson (2005), commitment is one of the fundamental relationship constructs that is most widely used to satisfy customers. Trisnaningsih, (2003) argued that commitment has been widely recognized as an integral part of any business relationship. Commitment is a long-term relationship that is an important element in success and trust and customer satisfaction. Wijayawati \& Jaka (2004) provided evidence of a significant positive impact on employee commitment to the formation of customer satisfaction.

The commitment of a service provider greatly impacts on customer loyalty. In this case, when the service provider is highly committed to providing services to its customers, it will make customers satisfied and then will not switch to other competitors and continue to use the service or product. Similarly, Yulianie et al (2003) viewed commitment as an important antecedent for customer loyalty. Setiawan (2007), in the results of his research, also revealed that there is a positive relationship between commitment and loyalty. Andini (2010) proved that commitment has a significant effect on loyalty with positive direction.

Customer satisfaction is considered important; therefore, it requires a strategy. Currently, the competitors are also trying as hard as possible. Although the cost of expenditure is very high, yet this is carried to win customers' hearts. Every company has a different impact in terms of customer satisfaction with loyalty and usage. Customer satisfaction does not mean that the customer is truly satisfied; however, it becomes a sense of loyalty that indicates that the customer is satisfied. There are 2 main things in customer satisfaction that include expectations and perceived performance. These two things are interrelated because if performance exceeds an expectation, satisfaction will create customer loyalty.

High customer satisfaction can also be supported by good communication between service providers and their customers. Musanto (2005) stated that communication is considered an important component in forming business relationships that can shape customer satisfaction. Safitri (2011) found that communication has a significant and positive effect on customer satisfaction. In addition, good communication will also have an impact on increasing customer loyalty as found in the research of Alawni et al (2015) which proved that there is a significant and positive effect of communication on customer satisfaction.

Then, handling customer complaint can also contribute to increasing customer satisfaction and loyalty. Similarly, Supriaddin et al (2015) stated that there is a significant and positive effect of handling customer complaint on customer satisfaction. Customers who make complaints must be properly resolved so that customers who previously feel dissatisfied, with the services, are then satisfied again and then stimulate customer loyalty. Based on this matter, this research was carried out with the title "Effect of Bank Commitment, Bank Communication and Handling Customer Complaint on Customer Loyalty Through Customer Satisfaction at PT Bank Central Asia Tbk of Mojopahit Mojokerto Sub-Branch Office".

\section{Research Method}

Research Design

This is a correlational research that uses a quantitative approach. Arikunto (2010) described the definition of the research as a type of correlation that aims to determine the level of relationship between variables without making changes, additions, or manipulations of the existing data. Furthermore, Sugiyono (2010) defined quantitative research as research that refers to positivist philosophy, which is used to examine certain samples. The sampling technique is generally done randomly, data collection is carried out using research instruments, data analysis is quantitative statistics with the aim of testing the predetermined hypotheses. 


\section{Population and Sampling Techniques}

Sugiyono (2010) defined that population is a region of generalization that is formed through objects and subjects with certain characteristics chosen by researchers and then studied for drawing the conclusion. The population used in this research are all customers of PT Bank Central Asia Tbk of Mojopahit Mojokerto Sub-Branch Office. The sampling technique chosen in this research is purposive sampling technique which obtained 165 samples from customers using several criteria. The following are the criteria used when in the research sampling:

1. Customers who have a transaction frequency of at least 5 transactions within 1 (one) month at PT Bank Central Asia Tbk of Mojopahit Mojokerto Sub-Branch Office.

2. Customers who have made a complaint regarding the services provided by PT Bank Central Asia Tbk of Mojopahit Mojokerto Sub-Branch Office in the last 1 (one) year.

The criteria set out above indicate that the respondent knew about PT Bank Central Asia Tbk of Mojopahit Mojokerto Sub-Branch Office.

\section{Research Instrument}

Instrument is tool needed for the process of collecting data (Kountur, 2007). In line with the opinion of Kountur (2007), the author gives the conclusion that the instrument referred to in this research is questionnaire. The questionnaire is used so that the research results remain in line with the research objectives. In addition to being compiled according to the research objectives, the questionnaire of this research is also prepared based on the theory that is in accordance with the research problems. In this research, the Likert scale is used as a measurement scale.

\section{Hypothesis Test}

Research requires a data analysis and interpretation that will be used to answer research questions and uncover certain social phenomena. Therefore, data analysis is the process of simplifying data into a form that is easier to read and interpret. The research model that will be used in this research is a tiered structure model. In addition, the hypothesis testing applies SEM (Structural Equation Modeling) analysis techniques which are operated through the AMOS program.

The reason stated is related to the use of SEM where SEM is a set of statistical techniques that allow simultaneous testing of a series of relatively "complicated" correlations. Modeling through SEM also allows a researcher to answer both regressive and dimensional research questions (i.e. measuring what dimensions of a concept are) (Ferdinand, 2005). Analysis of the research model using SEM makes it possible to identify the dimensions of a construct and at the same time measure the effect or degree of relationships between factors whose dimensions have been identified.

\section{Assumption Testing of SEM (Structural Equation Model)}

The principle of hypothesis testing model assumptions, i.e. assumptions related to the model and assumptions related to parameter estimation and hypothesis testing as: linearity assumptions, assumptions about the absence of outliers, and the assumption of normal distribution. 


\section{Research Results and Discussion}

Hypothesis Testing

Hypothesis testing was carried out using $\mathrm{P}=0.05$; therefore, the critical ratio of the structural equation must be $\geq 1.97$ and the results are as follows:

Table 1. Hypothesis Testing

\begin{tabular}{|c|c|c|c|c|c|c|c|}
\hline & & & Estimate & S.E. & C.R. & $\mathrm{P}$ & Description \\
\hline Z & $<--$ & X1 & 0.312 & 0.094 & 3.469 & 0.000 & Significant \\
\hline Y & $<--$ & X1 & 0.193 & 0.094 & 2.017 & 0.044 & Significant \\
\hline Z & $<---$ & $\mathrm{X} 2$ & 0.311 & 0.114 & 3.318 & 0.000 & Significant \\
\hline Y & $<--$ & $\mathrm{X} 2$ & 0.251 & 0.115 & 2.494 & 0.013 & Significant \\
\hline Z & $<--$ & X3 & 0.207 & 0.096 & 2.322 & 0.020 & Significant \\
\hline Y & $<--$ & X3 & 0.224 & 0.096 & 2.365 & 0.018 & Significant \\
\hline Y & $<--$ & $\mathrm{Z}$ & 0.260 & 0.101 & 2.414 & 0.016 & Significant \\
\hline
\end{tabular}

Based on Table 1 above, the results of hypothesis testing can be explained as follows:

1. The CR value between Bank Commitment and Customer Satisfaction is 3.469 with a probability value of 0.000 or $p<0.05$. It shows that the Bank Commitment variable has a significant effect on Customer Satisfaction variable at BCA of Mojopahit Mojokerto Sub-Branch Office.

2. The CR value between Bank Commitment and Customer Loyalty is 2.017 with a probability of 0.044 or $\mathrm{p}<0.05$. It shows that the Bank Commitment variable has a significant effect on the Customer Loyalty variable at BCA of Mojopahit Mojokerto Sub-Branch Office.

3. The CR value between Bank Communication and Customer Satisfaction is 3.318 with a probability of 0.000 or $p<0.05$. It shows that the Bank Communication variable has a significant effect on the Customer Satisfaction variable at BCA of Mojopahit Mojokerto Sub-Branch Office.

4. The CR value between Bank Communication and Customer Loyalty is 2.494 with probability of 0.013 or $\mathrm{p}<0.05$. It shows that the Bank Communication variable has a significant effect on the Customer Loyalty variable at BCA of Mojopahit Mojokerto Sub-Branch Office.

5. The CR value between Handling Customer Complaint and Customer Satisfaction is 2.322 with a probability of 0.020 or $\mathrm{p}<0.05$. It shows that the Handling Customer Complaint variable has a significant effect on the Customer Satisfaction variable at BCA of Mojopahit Mojokerto SubBranch Office.

6. The CR value between Handling Customer Complaint and Customer Loyalty is 2.365 with a probability of 0.018 or $\mathrm{p}<0.05$. It shows that the Handling Customer Complaint variable has a significant effect on the Customer Loyalty variable at BCA of Mojopahit Mojokerto Sub-Branch Office.

7. The CR value between Customer Satisfaction and Customer Loyalty is 2.414 with a probability of 0.016 or $p<0.05$. It shows that the Customer Satisfaction variable has a significant effect on the Customer Loyalty variable at BCA of Mojopahit Mojokerto Sub-Branch Office.

8. The estimate value of direct effect of Bank Commitment on Customer Loyalty is 0.193, which means that it is greater than the indirect effect through Customer Satisfaction $(0.312 \times 0.260=$ 
0.081). It shows that the Bank Commitment does not have a significant effect on Customer Loyalty through Customer Satisfaction at BCA of Mojopahit Mojokerto Sub-Branch Office.

9. The estimate value of the direct effect of Bank Communication on Customer Loyalty is 0.251, which means that it is greater than the indirect effect value through Customer Satisfaction $(0.311$ $\mathrm{x} 0.260=0.081)$. It shows that Bank Communication does not have a significant effect on Customer Loyalty through Customer Satisfaction at BCA of Mojopahit Mojokerto Sub-Branch Office.

10. The estimate value of the direct effect of Handling Customer Complaint on Customer Loyalty is 0.224 which means that it is greater than the indirect effect value through Customer Satisfaction $(0.207 \times 0.260=0.054)$. It shows that Handling Customer Complaint does not have a significant effect on Customer Loyalty through Customer Satisfaction at BCA of Mojopahit Mojokerto SubBranch Office.

Test of the Overall Model

Table 2. Evaluation of Criteria for Goodness of Fit Indices

\begin{tabular}{|l|l|l|l|l|}
\hline No. & Goodness of Fit Crit & Result & Cut-off Value & Model Evaluation \\
\hline 1. & Chi-square $(\chi 2)$ & 213.787 & Expected to be small & Fit \\
\hline 2. & Probability $(\rho)$ & 0.053 & $>0.05$ & Fit \\
\hline 3. & RMSEA & 0.033 & $<0.8$ & Fit \\
\hline 4. & GFI & 0.895 & $0.80-0.90$ & Fit \\
\hline 5. & AGFI & 0.867 & $0.80-0.90$ & Fit \\
\hline 6. & CMIN/DF & 1.175 & $<2.0$ & Fit \\
\hline 7. & TLI & 0.974 & $>0.90$ & Fit \\
\hline 8. & CFI & 0.970 & $>0.90$ & Fit \\
\hline
\end{tabular}

Based on Table 2, all values of goodness of fit are fit and in accordance with the cut-off value. Thus, it is concluded that the empirical data used is in accordance with the conceptual framework.

\section{Discussion}

Effect of Bank Commitment on Customer Satisfaction

The results of data analysis show that bank commitment has a significant and positive effect on customer satisfaction. That is indicated by the testing carried out on the customer satisfaction variable. The CR value generated by the bank commitment variable is 3.469 with a probability value of 0.000 or $p$ $<0.05$. Thus, the first research hypothesis which states that "bank commitment has a significant effect on customer satisfaction at BCA of Mojopahit Mojokerto Sub-Branch Office" is accepted.

According to Hersey et al (2007), commitment is defined as the power that binds individuals to actions that are relevant to one or more targets. In addition, commitment in the organization is defined as affective commitment (referring to the improvement of desire-based organizations), instrumental commitment (the client must remain in the organization), and normative commitment (referring to the obligation to remain in the organization). 
The results of the analysis indicate a positive effect on the bank commitment to customer satisfaction at BCA of Mojopahit Mojokerto Sub-Branch Office. It means that the higher the bank commitment, the higher customer satisfaction at BCA of Mojopahit Mojokerto Sub-Branch Office. In other words, customer satisfaction at BCA of Mojopahit Mojokerto High Sub-Branch Office can be formed with bank commitment owned by the company. Therefore, if BCA of Mojopahit Mojokerto SubBranch Office wants to increase customer satisfaction, they need to pay attention to the extent of their bank commitment. Commitment is one of the most basic constructs of relationship used to satisfy customers (Colquitt et al, 2011). Riketta (2002) stated that commitment has been widely recognized as an integral part of any business relationship. Commitment is an important element for successful long-term relationships, trust, and customer satisfaction.

The results of this research support the results of a research conducted by He et al (2011) who found that employee commitment had a positive and significant effect on customer satisfaction. This is also in line with Mascio's research (2015) that one's commitment affects his/her satisfaction.

\section{Effect of Bank Commitment on Customer Loyalty}

The results of data analysis show that bank commitment has a significant and positive effect on customer loyalty. That is indicated by the testing carried out on the customer loyalty variable. The CR value generated by the bank commitment variable is 2.017 with a probability value of 0.044 or $\mathrm{p}<0.05$. Thus, the second research hypothesis which states that "bank commitment has a significant effect on customer loyalty at BCA of Mojopahit Mojokerto Sub-Branch Office" is accepted.

The results of the analysis indicate the effect of the bank commitment to customer loyalty at BCA of Mojopahit Mojokerto Sub-Branch Office. It means that the higher the bank commitment, the higher customer loyalty at BCA of Mojopahit Mojokerto Sub-Branch Office. In other words, high customer loyalty at BCA of Mojopahit Mojokerto Sub-Branch Office can be formed with bank commitment of owned by the company. Therefore, if PT Bank Central Asia Tbk wants to increase customer loyalty, they need to pay attention to the extent of their bank commitment. Commitment is considered as an important antecedent for customer loyalty (Bricci et al, 2015).

The results of the research, which showed the effect of bank commitment on customer loyalty, are in line with the research conducted by Marshall (2010) where the results of the investigation found a positive relationship between commitment and loyalty. It also supports the results of a research conducted by Bricci et al (2015) that customers from the distribution sector in Portugal prove that commitment has a positive and significant effect on loyalty.

\section{Effect of Bank Communication on Customer Satisfaction}

The results of data analysis show that bank communication has a significant and positive effect on customer satisfaction. That is indicated by the testing carried out on the customer satisfaction variable. The CR value generated by the bank communication variable is 3.318 with a probability value of 0.000 or $\mathrm{p}<0.05$. Thus, the third research hypothesis which states that "bank communication has a significant effect on customer satisfaction at BCA of Mojopahit Mojokerto Sub-Branch Office" is accepted.

Communication is very important in a business. The existence of good communication between service providers and their customers will provide satisfaction to these customers. Similarly, Agung (2018) stated that communication is considered an important component in forming business relationships that can shape customer satisfaction.

Communication is the most important aspect because communication between employees from various departments of insurance companies and customers will achieve customer satisfaction (Kiswanto, 2010). The results of the analysis show the effect of bank communication on customer satisfaction at 
BCA of Mojopahit Mojokerto Sub-Branch Office. It means that the higher bank communication, the higher customer satisfaction at BCA of Mojopahit Mojokerto Sub-Branch Office. In other words, customer satisfaction at BCA of Mojopahit Mojokerto High Sub-Branch Office can be formed with bank communication owned by the company. Therefore, if BCA of Mojopahit Mojokerto Sub-Branch Office wants to increase customer satisfaction, they need to pay attention to the extent of their bank communication.

The results of this research support the results of the Saaty's (2011) research which discusses the importance of communication channels in ensuring better service quality and will ultimately provide more customer satisfaction in the context of insurance in Saudi. The same thing was proven by Agung (2018) that the communication of Sari Asih Hospital to customers has a significant and positive effect on customer satisfaction.

\section{Effect of Bank Communication on Customer Loyalty}

The results of data analysis show that bank communication has a significant and positive effect on customer loyalty. That is indicated by the testing carried out on the customer loyalty variable. The CR value generated by the bank communication variable is 2.494 with a probability value of 0.013 or $p$ < 0.05. Thus, the fourth research hypothesis which states that "bank communication has a significant effect on customer loyalty at BCA of Mojopahit Mojokerto Sub-Branch Office" is accepted.

The results of the analysis show the effect of bank communication on customer loyalty at BCA of Mojopahit Mojokerto Sub-Branch Office. It means that the higher banks communication, the higher customer loyalty at BCA of Mojopahit Mojokerto Sub-Branch Office. In other words, the high customer loyalty of BCA Mojopahit Sub-Branch Office can be formed with the bank communication to customers. Therefore, if BCA of Mojopahit Mojokerto Sub-Branch Office wants to increase customer loyalty, they need to pay attention to the extent of the bank communication with customers.

Saaty's research (2011) explained that communication channels are important in ensuring better service quality and will ultimately make more loyal customers in the context of Saudi insurance. The results of this research are in line with the results of Alawni et al's (2015) research that communication has a significant and positive effect on customer satisfaction.

\section{Effect of Handling Customer Complaint on Customer Satisfaction}

The results of data analysis show that handling customer complaint has a significant and positive effect on customer satisfaction. That is indicated by the testing carried out on the customer satisfaction variable. The $\mathrm{CR}$ value generated by the handling customer complaint variable is 2.322 with a probability value of 0.020 or $p<0.05$. Thus, the fifth research hypothesis which states that "handling customer complaint has a significant effect on customer satisfaction at BCA of Mojopahit Mojokerto Sub-Branch Office" is accepted.

Customers who make complaints must be properly resolved so that customers who were previously dissatisfied with the services provided become satisfied (Supriaddin et al, 2015). The reason behind the importance of handling/ resolving customer complaint in increasing satisfaction is the company's ability to handle and resolve complaints well and quickly to change the perception of customers who previously felt dissatisfied to be satisfied again because customers consider the company to have the ability to resolve complaints (Supriaddin et al. 2015). The results of the analysis show the effect of handling customer complaint on customer satisfaction at BCA of Mojopahit Mojokerto SubBranch Office. It means that the higher the handling customer complaints, the higher customer satisfaction at BCA of Mojopahit Mojokerto Sub-Branch Office. In other words, customer satisfaction at BCA of Mojopahit Mojokerto High Office Sub-Branch can be formed by handling customer complaints. 
Therefore, if the BCA of Mojopahit Mojokerto Sub-Branch Office wants to increase customer satisfaction, they need to pay attention to the extent of handling customer complaint by the bank.

The results of this research support the results of research conducted by Supriaddin et al (2015) which showed that handling customer complaint has a significant and positive effect on customer satisfaction.

\section{Effect of Handling Customer Complaint on Customer Loyalty}

The results of data analysis show that handling customer complaint has a significant and positive effect on customer loyalty. That is indicated by the testing carried out on the customer loyalty variable. The CR value generated by the handling customer complaint variable is 2.365 with a probability value of 0.018 or $p<0.05$. Thus, the sixth research hypothesis which states that "handling customer complaint has a significant effect on customer loyalty at BCA of Mojopahit Mojokerto Sub-Branch Office" is accepted.

The bank's ability to handle customer complaint will stimulate customer loyalty (Oly Ndubisi, 2007; Supriaddin et al, 2015). The logical framework behind this idea is that customer good and fair experience in complaint handling will create a perception that companies have a high level of attention on their customers. Therefore, it will direct customers to give positive reviews by word of mouth. Thus, the company's reputation will be better, customers will also continue to interact in the same bank and reject offers from other competitors (Supriaddin et al, 2015).

The results of the analysis show the effect of handling customer complaint on customer loyalty at BCA of Mojopahit Mojokerto Sub-Branch Office. It means that the higher the handling customer complaint, the higher customer loyalty at BCA of Mojopahit Mojokerto Sub-Branch Office. In other words, customer loyalty at BCA of Mojopahit Mojokerto High Office Sub-Branch can be formed by handling customer complaint. Therefore, if the BCA of Mojopahit Mojokerto Sub-Branch Office wants to increase customer loyalty, they need to pay attention to the extent to which customer complaints are handled.

The results of this research support the results of a research conducted by Supriaddin et al (2015) that handling customer complaint has a significant and positive effect on customer loyalty.

\section{Effect of Customer Satisfaction on Customer Loyalty}

The results of data analysis show that customer satisfaction has a significant and positive effect on customer loyalty. That is indicated by the testing carried out on the customer loyalty variable. The CR value generated by the customer satisfaction variable is 2.414 with a probability value of 0.016 or $\mathrm{p}<$ 0.05. Thus, the seventh research hypothesis which states that "customer satisfaction has a significant effect on customer loyalty at BCA of Mojopahit Mojokerto Sub-Branch Office" is accepted.

This is similar to what revealed by Al-Msallam (2015) that customers who are satisfied with the product or service are more likely to repeat purchases and recommend their consumption experience to others. Oliva et al in Al-Msallam (2015) also stated that in the relationship between customer loyalty and customer satisfaction, customer loyalty will increase significantly when satisfaction reaches a certain level and at the same time customer loyalty will drop dramatically if the satisfaction level drops to the point certain. Customers who feel very satisfied tend to be more loyal than customers who are only satisfied (Al-Msallam, 2015).

The results of the analysis show the effect of customer satisfaction on customer loyalty at BCA of Mojopahit Mojokerto Sub-Branch Office. It means that the higher customer satisfaction, the higher customer loyalty will be at BCA of Mojopahit Mojokerto Sub-Branch Office. In other words, high customer loyalty at BCA of Mojopahit Mojokerto Sub-Branch Office can be formed with customer 
satisfaction. Therefore, if the BCA of Mojopahit Mojokerto Sub-Branch Office wants to increase customer loyalty, they need to pay attention to the extent of customer satisfaction.

The results of this research are in line with the results of research conducted by Al-Msallam (2015) who found that customer satisfaction has a significant effect on customer loyalty. It is similar to the results of research conducted by Chiguvi and Guruwo (2015) who found the existence of a positive and significant effect between customer satisfaction on customer loyalty.

\section{Effect of Bank Commitment on Customer Loyalty Through Customer Satisfaction}

The results of hypothesis testing indicate that bank commitment does not have a significant effect on customer loyalty through customer satisfaction. It is indicated by the direct effect value of bank commitment on customer loyalty of 0.193 which is greater than the indirect effect value through customer satisfaction $(0.312 \times 0.260=0.081)$. It means that customer loyalty at BCA of Mojopahit Mojokerto SubBranch Office can be increased using bank commitment without going through customer satisfaction.

The results of the research show that the bank commitment does not have a significant effect on customer loyalty through customer satisfaction. Thus, the eighth research hypothesis which states that "customer satisfaction can mediate the effect between bank commitment and customer loyalty at BCA of Mojopahit Mojokerto Sub-Branch Office", is rejected.

\section{Effect of Bank Communication on Customer Loyalty Through Customer Satisfaction}

The results of hypothesis testing indicate that bank communication does not have a significant effect on customer loyalty through customer satisfaction. It is indicated by the direct effect value of bank communication on customer loyalty of 0.251 which is greater than the indirect effect value through customer satisfaction $(0.311 \times 0.260=0.081)$. It means that customer loyalty at BCA of Mojopahit Mojokerto Sub-Branch Office can be increased using bank communication without going through customer satisfaction.

The findings of this research indicate that customer satisfaction cannot mediate the effect of bank commitment on customer loyalty significantly. Thus, the ninth research hypothesis which states that "customer satisfaction can mediate the effect of bank communication on customer loyalty at BCA of Mojopahit Mojokerto Sub-Branch Office", is rejected.

\section{Effect of Handling Customer Complaint on Customer Loyalty Through Customer Satisfaction}

The results of hypothesis testing that have been conducted indicate that handling customer complaint does not have a significant effect on customer loyalty through customer satisfaction. It is indicated by the direct effect value of handling customer complaint on customer loyalty of 0.224 which is greater than the indirect effect value through customer satisfaction $(0.207 \times 0.260=0.054)$. It means that customer loyalty at BCA of Mojopahit Mojokerto Sub-Branch Office can be increased using the handling customer complaint without going through customer satisfaction.

The findings of this research indicate that customer satisfaction cannot mediate the effect of handling customer complaint on customer loyalty significantly. Thus, the tenth research hypothesis which states that "customer satisfaction can mediate the effect between handling customer complaint and customer loyalty at BCA of Mojopahit Mojokerto Sub-Branch Office", is rejected. 


\section{Conclusion}

Based on the results of the analysis described previously, the conclusions in this research include:

1. Bank commitment has a significant effect on customer satisfaction at BCA of Mojopahit Mojokerto Sub-Branch Office. Thus, the research hypothesis states that "bank commitment has a significant effect on customer satisfaction at BCA of Mojopahit Mojokerto Sub-Branch Office" is accepted.

2. Bank commitment has a significant effect on customer loyalty at BCA of Mojopahit Mojokerto Sub-Branch Office. Thus, the research hypothesis states that "bank commitment has a significant effect on customer loyalty at BCA of Mojopahit Mojokerto Sub-Branch Office" is accepted.

3. Bank communication has a significant effect on customer satisfaction at BCA of Mojopahit Mojokerto Sub-Branch Office. Thus, the research hypothesis states that "bank communication has a significant effect on customer satisfaction at BCA of Mojopahit Mojokerto Sub-Branch Office" is accepted.

4. Bank communication has a significant effect on customer loyalty at BCA of Mojopahit Mojokerto Sub-Branch Office. Thus, the research hypothesis states that "bank communication has a significant effect on customer loyalty at BCA of Mojopahit Mojokerto Sub-Branch Office" is accepted.

5. Handling customer complaint has a significant effect on customer satisfaction at BCA of Mojopahit Mojokerto Sub-Branch Office. Thus, the research hypothesis states that "handling customer complaint has a significant effect on customer satisfaction at BCA of Mojopahit Mojokerto Sub-Branch Office" is accepted.

6. Handling customer complaint has a significant effect on customer loyalty at BCA of Mojopahit Mojokerto Sub-Branch Office. Thus, the research hypothesis states that "handling customer complaint has a significant effect on customer loyalty at BCA of Mojopahit Mojokerto SubBranch Office" is accepted.

7. Customer satisfaction has a significant effect on customer loyalty at BCA of Mojopahit Mojokerto Sub-Branch Office. Thus, the research hypothesis states that "customer satisfaction has a significant effect on customer loyalty at BCA of Mojopahit Mojokerto Sub-Branch Office" is accepted.

8. Customer satisfaction can mediate the effect between the bank commitment and customer loyalty at BCA of Mojopahit Mojokerto Sub-Branch Office. Thus, the research hypothesis states that "customer satisfaction can mediate the effect between the bank commitment to customer loyalty at BCA of Mojopahit Mojokerto Sub-Branch Office" is accepted.

9. Customer satisfaction can mediate the effect between bank communication and customer loyalty at BCA of Mojopahit Mojokerto Sub-Branch Office. Thus, the research hypothesis states that "customer satisfaction can mediate the effect between bank communication on customer loyalty at BCA of Mojopahit Mojokerto Sub-Branch Office" is accepted.

Customer satisfaction can mediate the effect between handling customer complaint and customer loyalty at BCA of Mojopahit Mojokerto Sub-Branch Office. Thus, the research hypothesis states that "customer satisfaction can mediate the effect between handling customer complaint to customer loyalty at BCA of Mojopahit Mojokerto Sub-Branch Office" is accepted. 


\section{References}

Agung, N. W. A. (2018). "The Impact of Interpersonal Communication toward Customer Satisfaction: The Case of Customer Service of Sari Asih Hospital". MATEC Web of Conferences 150, University of Prof. Dr. Moestopo (Beragama), Jakarta, Indonesia.

Alawni, M. S., Yusoff, R. Z., Al-Swidi, A. K., \& Al-Matari, E. M. (2015). The relationship between communication, customer knowledge and customer loyalty in Saudi Arabia insurance industry companies. Mediterranean Journal of Social Sciences, 6(1), 318.

Al-Msallam, S. (2015). "The Relationship between Customer Satisfaction and Customer Loyalty in the Banking Sector in Syria”. Journal of Marketing and Consumer Research 7 : 27-36.

Andini, R. (2010). Analisis pengaruh kepuasan gaji, kepuasan kerja, komitmen organisasional terhadap turnover intention. Dinamika Sains, 8(16).

Arikunto. (2010). Prosedur Penelitian: Suatu Pendekatan Praktek. Jakarta: Rineka Cipta.

Bricci, L., Fragata, A., \& Antunes, J. (2016). The effects of trust, commitment and satisfaction on customer loyalty in the distribution sector. Journal of Economics, Business and Management, 4(2), 173-177.

Chiguvi, D., \& Guruwo, P.T. (2015). "Impact of Customer Satisfaction on Customer Loyalty in the Banking Sector". International Journal of Scientific Engineering and Research (IJSER). 5 (2): 55-63.

Colquitt, J., Lepine, J. A., Wesson, M. J., \& Gellatly, I. R. (2011). Organizational behavior: Improving performance and commitment in the workplace (Vol. 375). New York, NY: McGraw-Hill Irwin.

Danibrata, A. (2011). Pengaruh IntegratedMarketing Communication terhadapBrand Equity pada sebuah BankPemerintah di Jakarta. Jurnal Bisnis dan Akuntansi, 13(1): 21-38.

Ferdinand, A. (2005). Metode Penelitian Manajemen. Edisi 2. Semarang : BP Universitas. Diponogoro.

He, Y., Li, W., \& Keung Lai, K. (2011). Service climate, employee commitment and customer satisfaction: evidence from the hospitality industry in China. International Journal of Contemporary Hospitality Management, 23(5), 592-607.

Hersey, P., Blanchard, K. H., \& Johnson, D. E. (2007). Management of organizational behavior (Vol. 9). Upper Saddle River, NJ: Prentice hall.

Kiswanto, M. (2010). Pengaruh Kepemimpinan dan Komunikasi Terhadap Kinerja Karyawan Kaltim Pos Samarinda. Jurnal Eksis, 6(1), 1429-1439.

Kountur, R. (2007). Metode Penelitian untuk penulisan Skripsi dan Tesis, edisi revisi. Jakarta: PPM.

Marshall, P. D. (2010). "The promotion and presentation of the self: celebrity as marker of presentational media". Journal Celebrity Studies 1 (1) : 35 - 48. 
Mascio. (2015). "Modelling roles of commitment on rapport and satisfaction", International Journal of Bank Marketing. 33 (3).

Musanto, T. (2005). Faktor-faktor kepuasan pelanggan dan loyalitas pelanggan: Studi kasus pada CV. Sarana Media Advertising Surabaya. Jurnal Manajemen dan Kewirausahaan, 6(2), 123-136.

Oly Ndubisi, N. (2007). Relationship marketing and customer loyalty. Marketing intelligence \& planning, 25(1), 98-106.

Riketta, M. (2002). Attitudinal organizational commitment and job performance: a meta-analysis. Journal of Organizational Behavior: The International Journal of Industrial, Occupational and Organizational Psychology and Behavior, 23(3), 257-266.

Robinson. 2005. Pengaruh Komitmen Organisasi, Kepuasan Kerja dan Keperilakuan Etis TerhadapKeinginan Berpindah pada Profesional Bidang Teknologi Informasi. Jurnal Bisnis \& Manajemen.Vol. 5, No. 1, pp: 23-24.

Safitri, Y. A. (2011). Kepercayaan, komitmen, komunikasi, penanganan konflik, dan perannnya terhadap kepuasan terhadap loyalitas nasabah bank BCA di Surabaya. Journal of Business \& Banking, 1(2), 117-130.

Setiawan, M. B. (2007). Pengaruh Kualitas Layanan, Kepercayaan dan Komitmen Terhadap Loyalitas Nasabah (Studi pada PD. BPR Bank Pasar Kendal). Jurnal Bisnis dan Ekonomi, 14(2).

Sugiyono. (2009). Metode Penelitian Kuantitatif, Kualitatif dan $R \& D$, Bandung : Alfabeta.

Sugiyono. (2010). MetodePenelitian Kuantitatif Kualitatif \& RND. Bandung : Alfabeta.

Supriaddin, N., Palilati, A., Bua, A., \& Patwayati, J. H. (2015). The effect of complaint handling toward customer satisfaction, trust and loyalty to bank rakyat Indonesia (Bri) southeast Sulawesi. Int. J. Eng. Sci.(IJES), 4(6), 01-10.

Trisnaningsih, S. (2003). Pengaruh Komitmen terhadap Kepuasan Kerja Auditor: Motivasi sebagai Variabel Intervening. Jurnal Riset Akuntansi Indonesia.Vol 6. No 2. Mei 2003. hal 199-216.

Wijayawati, N., \& Jaka, W. (2004). Pengaruh Organizational Based Self EsteemTerhadap Keinginan Pindah: Komitmen Organisasi Sebagai Variabel Intervening. Jurnal Bisnis dan Manajemen. Vol. 4. No. 2 hal. 130-149.

Yulianie, N., Sutyas, P., \& Frikson, C. S. (2003). Rasa Percaya, Komitmen Organisasi dan Rasa Berdaya Tim (Empowered Team) Pada Karyawan Instansi Pemerintah di Surabaya. Anima Indonesian Psychological Journal, 18(3), 255-273.

\section{Copyrights}

Copyright for this article is retained by the author(s), with first publication rights granted to the journal. This is an open-access article distributed under the terms and conditions of the Creative Commons Attribution license (http://creativecommons.org/licenses/by/4.0/). 